\title{
Self-Acceptance from Aqidah and Gender Perspectives
}

\author{
$1^{\text {st }}$ Vina Akmala Ilma* \\ Faculty of Social Sciences and Humanities \\ Sunan Kalijaga State Islamic University \\ Yogyakarta Indonesia \\ vinaakmalailma@outlook.com
}

\author{
$2^{\text {nd }}$ Zidni Immawan Muslimin \\ Faculty of Social Sciences and Humanities \\ Sunan Kalijaga State Islamic University \\ Yogyakarta Indonesia \\ zidni_psiko@yahoo.com
}

\begin{abstract}
This research seeks to determine the relationships between aqidah and self-acceptance, as well as the gender differences in self-acceptance. This research is a quantitative study, using quota sampling as a sampling technique. This study involved 215 students that were spreading in several universities in Special Region of Yogyakarta. The instrument used in this research was a modification of the Unconditional Self-acceptance Questionnaire (USAQ) which had an alpha coefficient of 0,841 and Aqidah Scale which had an alpha coefficient of 0,893 . The first hypothesis for the relationship between aqidah and selfacceptance was analyzed by non-parametric spearman rho that showed insignificant result. This means there is no significant relationship between aqidah and self-acceptance. The second hypothesis for the comparison of self-acceptance between men and women that analyzed by independent sample t-test showed significant differences, which is men had higher self-acceptance than women.
\end{abstract}

Keywords: aqidah, gender, self-acceptance, Muslim students

\section{INTRODUCTION}

According to BPS (Badan Pusat Statistik), $50 \%$ of the productive age population currently comes from the millennial generation, even in 2020 to 2030 it is estimated that the number will reach $70 \%$ of the productive age population [1]. Beside of the great number of its population, the prevalence of mental disorders in Indonesia from 20132018 was increased $4.8 \%$ from $5.8 \%$ to $10 \%$ [2]. Therefore, to be able to compete in this increasingly modern era, it is important for the millennials to pay attention to their mental health.

Relating to this matter, Carson and Langer, as quoted in [3], found that self-acceptance is very important for mental health. According to Hurlock [4], self-acceptance helps someone to accept everything that exists in themselves - both their weaknesses and strengths - so that if an unpleasant event occurs, they will be able to think logically about the problem that has happened without causing them feelings of hostile, inferior, shame, and insecure.

Acceptance of physical conditions and self-quality according to William Kay, as quoted by [5] is one of the tasks of adolescent development. If adolescents fail to fulfill their developmental tasks, they will have negative consequences in their social life in the subsequent developmental phases, so it will lead them feel unhappy, community rejection, and difficulties in completing the tasks of subsequent development [6].
In fact, millennial generations now showing behavior that reflect lack of self-acceptance. In line with the research conducted by Simanjuntak [7], there were $72 \%$ of 179 students who had a moderate level of self-acceptance and $14 \%$ of students who had low self-acceptance. In addition, a a research from Yahya [8] also found that there were $41 \%$ of 60 students who had low self-acceptance.

According to the ZAP Beauty Index survey in 2018 of 17,889 women, there were $35.9 \%$ of women from millennial generations and $48.9 \%$ of women aged $18-23$ years who were not confident about their physical condition [9]. Meanwhile, according to the research of Sugiar and Dieny [10] of 88 male students, there were $57.9 \%$ of males feeling dissatisfied with their physical condition. Body dissatisfaction then encourages someone to increase their efforts to get the ideal body [11]

The lack of confidence in physical condition that occurs among millennials [9] mean that they are not confident in their own abilities so they are affected by others and cannot act according to their own will [12]. At the same time, their dissatisfaction with the physical condition [11] shows a negative self-assessment [13] that they are unattractive and tendency to compare the body shape they have with the ideal body shape [14]. These three points are aspects of unconditional self- acceptance expressed by Albert Ellis, as quoted in [15].

Not only in physical terms, lack of self-acceptance can also be found among students who are unable to express their opinions, answer questions, refute arguments during lectures or during discussions. This inability is because they do not respect themselves, where they assume that what they said was not right and would not be accepted. In other words, they have low self-esteem [16].

The lack of self-acceptance is caused by several factors, one factor is religiosity [17, 18]. According to Sulthon [18], a good pattern of religiosity will generate good religious appreciation, then self-awareness and self-surrender to God will be improved so that self-acceptance will be achieved. As quoted Glock \& Stark in [19], one of the dimensions of religiosity is religious belief . In the Islamic perspective, the dimension of religious belief can then be referred to "aqidah" [19].

According to Hurlock [20], self-acceptance can be influenced by obstacles from the environment that cannot be controlled, including in this case is gender. In other literatures it is mentioned that gender is one of the factors 
that influence psychological well-being, which selfacceptance is one of its dimensions. Gender differences play important role in psychological well-being, because of the many efforts being made in contemporary society to empower all individuals, both men and women, to achieve self-actualization and utilize the potential they have as much as possible [21].

Some researchers showed inconsistent results. In a research conducted by Chraif \& Dumitru [22] of students majoring in psychology at the University of Bucharest showed a significant difference in self-acceptance between men and women $($ Mmen $=21.08<$ Mwomen = 31.90). In contrast to [21] who found that men significantly had higher acceptance than women. Similarly, Sagone \& Caroli [23] found that there were significant differences acceptance of adolescent between boys and girls (Mboys $=12.16>$ Mwomen $=10.83)$. Because of this inconsistency, the researcher tended to use gender differences as second independent variable in this research.

\section{THEORETICAL FRAMEWORK}

According to Ellis, as quoted in [24], Unconditional SelfAcceptance (USA) means that the individual fully and unconditionally accepts himself no matter he behaves intelligently, correctly, or competently and does not care of others approve, respect, or love him. There are ten facets of USA; 1) Belief that one's self-worth is bestowed simply by virtue of being; 2) Belief that no one is worth more than anyone else; 3) Tendency to set goals based on a pursuit of intrinsic satisfaction and enjoyment rather than enhancement o f self-worth; 4) General avoidance of the tendency to; 5) Objective awareness of one's strengths and limitations (but without global appraisals on the basis of these strengths and limitations); 6) Tendency to respond to failure and negative feedback with some unhappiness about thwarted goals, but not as indicative of lower self-worth; 7) Tendency to respond to failure and negative feedback as informative about areas for behavioral improvement; 8) Tendency to respond to success and positive feedback as informative about areas of strength, but not with a sense of being a better person because of the success; 9) Sense of self- worth independent of others' approval; 10) General avoidance of the tendency to compare one's worth with others.

Aqidah (religious belief) is something that are believed to be true by your heart, bringing tranquility to the soul, and becoming belief without doubting any of it [25]. Relating to this case, aqidah is believing in five things, which we call pillars of aqidah: Allah, Angels, Books, Apostles, Judgment Day and Qadha and Qadar. Because of this, aqidah becomes important for individuals to fully accept themselves, with it someone believes that what is given by God is the best gift that must be respected, even though according to other people it's a bad thing. According to [25], aqidah is divided into four main dimensions, namely: al-Ilahiyat, anNubuwwat, ar-Ruhaniyat and as-Sam 'iyyat.

a. Ilahiyat, a discussion of everything related to Illah (God), such as the form of God, the names of Allah, the qualities that must be in Allah, and others.

b. Nubuwwat, a discussion of everything related to the apostles of God, including scriptures, miracles, and others. c. Ruhaniyat, a discussion of everything related to the spirit or metaphysical realms, such as angels, jinn, demons, and spirits, and others

d. Sam'yyat, a discussion about everything that can only be known through sam'i (theorem Naqli: Al Quran and Sunnah), such as heaven, hell, nature barzakh, akhirat, apocalypse and others.

\section{RESULT AND DISCUSSION}

The sample consisted of undergradute 215 students who are muslim and spreading in several universities in Special Region of Yogyakarta. Self-acceptance was measured by modification of the Unconditional Self-acceptance Questionnaire (USAQ) from [24] which is previously adapted by Hasmalawati [26]. This scale is 22 items with a discrimination power above 0.25 and a reliability coefficient of 0.841. And then, aqidah scale was compiled by [27] based on the Banna's theory which states the aqidah of aspects of Ilahiyat, Nubuwwat, Ruhaniyat, and Sam'iyyat. The aqidah scale is 31 items with a discrimination power above 0.30 and a reliability coefficient of 0.893 .

The following tables are assumption of normality, linearity and homogenity test which were carried out before a statistical test.

Table. 1 Normality Test

\begin{tabular}{lcc}
\hline Variable & $\begin{array}{c}\text { Normal } \\
(\mathrm{p}>0.05)\end{array}$ & Description \\
\hline Aqidah & 0.000 & is not normal \\
USA & 0.200 & normal \\
\hline
\end{tabular}

Based on the table, it is known that the significance level of the self-acceptance variable is 0.20 ( $>>0.05$ ) and the aqidah variable is 0.00 ( $\mathrm{p}<0.05)$. Because the significance level of unconditional self-acceptance variable is more than 0.05 then the data distribution is normal. But the significance level of the aqidah scale is less than 0.05 , so the data distribution is abnormal. Because of the research data do not meet the normality assumption test, the hypothesis testing is performed using non-parametric statistical techniques, namely Spearman rho.

Table. 2 Linierity Test

\begin{tabular}{lccl}
\hline Variable & F & $\begin{array}{c}\text { Linier } \\
(\mathrm{p}<0.05)\end{array}$ & Description \\
\hline $\begin{array}{l}\text { Aqidah } \\
\text { and USA }\end{array}$ & 0.792 & 0.375 & is not linier \\
\hline
\end{tabular}

The result of the linierity test above showed that the relationship between aqidah and USA is not linier.

Table. 3 Homogenity Test

\begin{tabular}{lccc}
\hline Variable & $\begin{array}{c}\text { Levene } \\
\text { Statistic }\end{array}$ & $\begin{array}{c}\text { Homogen } \\
(\mathrm{p}>0.05)\end{array}$ & Description \\
\hline $\begin{array}{l}\text { Gender } \\
\text { and USA }\end{array}$ & 0.006 & 0.939 & homogen \\
\hline
\end{tabular}

The results of the homogenity test above showed that the data between gender and USA is homogen. 
Table. 4 Hypothesis Test

\begin{tabular}{lccc}
\hline Variable & $\begin{array}{c}\text { Spearman } \\
\text { rho }\end{array}$ & $\begin{array}{c}\mathrm{p} \\
(\mathrm{p}<0.05)\end{array}$ & Description \\
\hline $\begin{array}{l}\text { Aqidah } \\
\text { and USA }\end{array}$ & 0.510 & 0.227 & Rejected \\
\hline
\end{tabular}

Based on the table above it is known that the relationship between aqidah and USA has a correlation coefficient of 0.510 with a significance level of 0.227 . Hypothesis is rejected because $p>0.05$, which means that there is no significant relationship between the two variables.

Table. 5 Hypothesis Test

\begin{tabular}{lccc} 
Variable & $\mathrm{t}$ & $\begin{array}{c}\mathrm{p} \\
(\mathrm{p}<0.05)\end{array}$ & Description \\
\hline $\begin{array}{l}\text { Gender } \\
\text { and USA }\end{array}$ & 2.124 & 0.035 & Accepted \\
\hline
\end{tabular}

The table above showed that the second hypothesis is accepted. It means there are significant gender differences in USA, that men had higher self-acceptance than women.

The significance level of normality test of the aqidah scale is $0.00(\mathrm{p}<0.05)$, so the data distribution is abnormal. Data abnormality of the aqidah scale is caused by too much extreme data so that the distribution of data tends to be skewed (skewness) to the right. In other words, the answers given by most subjects are "Strongly Agree" that has a value of 4 and "Agree" that has value of 3 , so that the variation of the choices "Disagree" and "Strongly Disagree" become so little. After reviewing the aqidah scale, we found that some items contained in the aqidah scale tend to contain normative items with responses agree / disagree. One example of the item is item number 2 which is reads, "I still have to endeavor even though God has determined my destiny."

In addition to aqidah scale that are less valid, the characteristics of the sample used in this study may also affect the relationship between aqidah and self-acceptance. Several studies that proved religiosity is significantly correlated with self-acceptance contained sample characteristics that have certain obstacles, for example a blind person [18], diabetics [28], ischemic stroke sufferers [29] and parents who have children with autism [17]. In contrast to them, some research showed that there is no significant relationship between religiosity and selfacceptance. One such research was a research conducted by Glass [30] of African American women aged 18-65 years, that intrinsic religious and extrinsic religious had no significant relationship with self-acceptance. Other research of 187 subjects aged 19 to 62 years also found that the relationship between the religious meaning system and selfacceptance was not significant [31].

The second hypothesis in this research was analyzed using independent sample t-test. The hypotesis is accepted, so there is a significant gender differences in unconditional self-acceptance, that men had higher self-acceptance women. Composite score of self-acceptance mean score for men (M =92.24), women $(\mathrm{M}=87.41)$ and total sample $(\mathrm{M}=88.91)$.
According to Bem \& Lanny as quoted in Andersen [32], traditional sex roles may restrict the enactment of useful and common behaviors, possibly in a dysfunctional manner. This statement is consistent with findings of previous research by Gray as quoted in [32], who have reported sex-typed individuals of both sexes to experience high anxiety, and when specifically feminine-typed, according to research conducted by Sears to show low self-esteem [32]. In addition, the views that show women as intellectual and career figures are still very few when compared to men. Women's representation in accordance with the spirit of women's emancipation only appears in the commemoration of Kartini Day, Mother's Day, and other momentum associated with women [33]. Therefore, women who are affected by this stereotype find it more difficult to accept themselves than men who are considered more free in their will.

The results of the second hypothesis test in this study are in line with the research of [21] who found that significantly men had higher acceptance than women. According to [21], what causes men to have better self- acceptance than women is they do not base their identity on appearance-related attributes, but on competence related attributes. Similarly, Sagone \& Caroli [23] found that there are significant differences in self-acceptance of adolescent between boys and girls $\left(\mathrm{M}_{\text {boys }}=12.16>\mathrm{M}_{\text {girls }}=10.83\right)$.

As we already know based on the results of the research above, that the gender differences play important role in achieving unconditional self-acceptance. So, it is important to always keep in mind that all people are equal, but not the same. Learning more about gender differences may lead to greater opportunities for self-actualisation and the further promotion of optimal psychological well-being in both men and women. The more knowledge about it may also help to identify and improve historical imbalances between resources, opportunities and protective factors for men and women [21].

\section{CONCLUSION}

Based on the explanation of the study above, it is concluded that the relationship between aqidah and unconditional self-acceptance is not significant. This result is indicated by the correlation coefficient of 0.51 and the significance level $\mathrm{p}=0.23(\mathrm{p}>0.05)$. The second hypothesis test in this study showed that there is a significant gender differences in uconditional self-acceptance, that men had higher self-acceptance than women. This result is indicated by the lever significance $\mathrm{p}=0.035(\mathrm{p}<0.05)$.

\section{REFERENCES}

[1] H. Ali, and L. Purwandi, "The urban middle class millenials Indonesia: financial and online behavior," PT Alvara Strategi Indonesia, 2017.

[2] M. Phangadi, "Peningkatan pengidap penyakit mental pada generasi Z periode 2013-2018," INA-Rxiv, 2019.

[3] D. Arli, and N. Sutanto, "Investigating the importance of self-acceptance and self-efficacy," International Journal of Nonprofit and Voluntary Sector Marketing, vol. 23, 2017, pp. 1-10 
[4] E.B. Hurlock, Psikologi perkembangan suatu pendekatan sepanjang rentang kehidupan, Jakarta: Erlangga, 2006.

[5] Y. Yahya, Psikologi Perkembangan, Jakarta: Kencana, 2011.

[6] K. Z. Putro, "Memahami ciri dan tugas perkembangan masa remaja," Aplikasia: Jurnal Aplikasi Ilmu-ilmu Agama, vol.17 (1), 2017, pp. 2532.

[7] D. F. Simanjuntak, "Gambaran penerimaan diri dan manfaat pendidikan psikologi pada mahasiswa psikologi jenjang sarjana," Thesis (unpublished), Fakultas Psikologi, Universitas Indonesia, 2013.

[8] F. Yahya, "Hubungan penerimaan diri dan motivasi akademik intrinsik pada mahasiswa yang kuliah tidak pada jurusan yang diinginkan," Thesis (unpublished), Fakultas Psikologi, Universitas Indonesia, 2013.

[9] ZAP Clinic, "ZAP beauty index," 2018, ZAP Clinic, <zapclinic.com/zap-beauty-index-download>.

[10] I. E. Sugiar, and F. F. Dieny, "Hubungan body image dengan asupan energi dan protein serta perilaku konsumsi suplemen pada mahasiwa di Semarang," Journal of Nutrition College, vol. 7 (1), 2018, pp. 3138 .

[11] Suprapto, M. Helena, M. P. Sari, and F. A. Nurcahyo, "Differences in men's body dissatisfaction based on the type of exercise motivation," Anima Indonesian Psychological Journal, vol. 31 (1), 2015, pp. 22-29.

[12] M.N, Ghufron, and R, Risnawita, Teori Teori Psikologi, Yogyakarta: Ar Ruzz Media, 2012

[13] S. Grogan, Body Image: Understanding Body Dissatisfaction in Men, Women and Children, New York: Routledge, 1999.

[14] J. Ogden, and C. Evans, "The problem of weighing: effects on body image, self esteem and mood," International Journal of Obesity, vol. 20 (3), 1996, pp. 272-277.

[15] J. M. Chamberlain, An empirical test of rationalemotive behavior therapy's unconditional selfacceptance theory, USA: UMI: Bell \& Howell Information and Learning, 1999.

[16] G. P. Wulandari, and D. Rosiana, "Hubungan selfesteem dengan perilaku asertif pada mahasiswa psikologi Universitas Islam Bandung angkatan 2015," Prosiding Psikologi, vol. 4 (2), 2018, pp. 455460.

[17] S. Rachmayanti, and A. Zulkaida, "Penerimaan diri orangtua terhadap anak autisme dan peranannya dalam terapi autisme," Jurnal Ilmiah Psikologi, vol. 1 (1), 2007, pp. 7-17.

[18] Sulthon, "Pola keberagamaan kaum tuna netra dan dampak psikologis terhadap penerimaan diri," Jurnal Quality, vol. 4 (1), 2016, pp. 45-68.
[19] M A. Subandi, Psikologi agama dan kesehatan mental, Yogyakarta: Pustaka Pelajar, 2016.

[20] E.B. Hurlock, Child development, USA: McGrawHill, 1978.

[21] B. Roothman, D. K. Kirsten, and M. P. Wissing, "Gender differences in aspects of psychological wellbeing," South African Journal of Psychology, vol. 33 (4), 2003, pp. 212-218.

[22] Chraif, Mihaela, and D. Dumitru, "Gender differences on wellbeing and quality of life at young students at psychology," Procedia - Social and Behavioral Sciences, vol. 180, 2015, pp. 1579-1583.

[23] E. Sagone, and M. E. D. Caroli, "Relationships between psychological well-being and resilience in middle and late adolescents," Procedia - Social and Behavioral Sciences, vol. 141, 2014, pp. 881 - 887.

[24] J. M. Chamberlain, and D. A. F. Haaga, "Unconditional self-acceptance and psychological health," Journal of Rational-Emotive \& CognitiveBehavior Therapy, vol. 19 (3), 2001, pp. 163-176.

[25] H. al-Banna. Aqidah Islam. Jakarta: al-Maarif, 1979.

[26] N. Hasmalawati, "Pengaruh citra tubuh dan perilaku makan terhadap penerimaan diri pada wanita," Jurnal Psikoislamedia, vol. 2 (2), 2017, pp. 107-115

[27] V. Victoriany, and Z. I. Muslimin, "Perilaku prososial ditinjau dari akidah dan perbedaan jenis kelamin pada mahasiswa muslim S1 di Daerah Istimewa Yogyakarta (DIY), " Thesis (unpublished), Fakultas Ilmu Sosial dan Humaniora, UIN Sunan Kalijaga, 2019

[28] H. Badaria, and Y. D. Astuti, "Religiusitas dan penerimaan diri pada penderita diabetes melitus," Psikologika : Jurnal Pemikiran dan Penelitian Psikologi, vol. 9 (17), 2004, pp. 21-30.

[29] D. I. Mukti, and D. S. K. Dewi, "Hubungan antara religiusitas dengan penerimaan diri pda pasien stroke iskemik di RSUD Banjarnegara," Psycho Idea, vol. 11 (2), 2013, pp. 35-40.

[30] Y. N. Glass, "African American women, psychological well-being, religiosity, and stress," Dissertation, College of Education, Health, and Human Services, Kent State University

[31] D. Krok, "The role of meaning in life within the relations of religious coping and psychological wellbeing," J Religion Health, 2014

[32] S. M. Andersen, "Sex-Role typing as related to acceptance of self, acceptance of others, and discriminatory attitudes toward woman," Journal of Research in Personality, vol. 12(4), 1978, pp. 410415

[33] E. D. Watie, "Representasi wanita dalam media massa masa kini, " Jurnal The Messenger, vol. II (2), 2010, pp. 1-10. 